\title{
Polymelia and duplication of the descending colon in a Poodle dog - a case report
}

\author{
Edmilson R. Daneze¹, and Fabrício B. J. Brasil2* \\ ${ }^{I}$ Department of Veterinary Clinic and Surgery, Faculty of Agricultural and Veterinary Sciences, São Paulo \\ State University, Jaboticabal, SP, Brazil \\ ${ }^{2}$ Veterinary Hospital, Faculty Dr. Francisco Maeda, Educational Foundation of Ituverava, Ituverava, SP, \\ Brazil
}

\section{DANEZE, E. R., F. B. J. BRASIL: Polymelia and duplication of the descending colon in a Poodle dog - a case report. Vet. arhiv 88, 149-157, 2018. \\ ABSTRACT}

This study describes a six-month old female Poodle dog born with a third hind limb and duplication of the descending colon. The extra limb was projected dorsally toward the coccygeal vertebrae and was slightly displaced to the left of the median body axis next to the anus. Although the animal walked without difficulties, it showed signs of discomfort when defecating and sitting. A plain radiograph demonstrated that the extra limb articulated from the left ischium and a contrast radiograph showed that the descending colon was not only duplicated but it adjoined the segments in the rectum, ending with one anal opening. Surgery was performed to amputate the extra limb. The disarticulation of the extra limb from the left ischium was easy to perform and minimally invasive. Intestinal intervention was not performed since it was determined that the animal could live a healthy life with the duplicated colon. Fifteen days after surgery the animal showed no signs of discomfort and was able to sit and defecate normally.

Key words: developmental anomaly; dog; colon duplication; embryology; polymelia; radiology

\section{Introduction}

Congenital malformations are innate structural abnormalities of organs, tissue and/or body systems that can occur during the embryonic development of all animal species, and may be partial or total (FELIPE, 2003; RADOSTITS et al., 2007). These malformations occur worldwide and can cause reproductive damage such as abortion, intra uterine stunted growth and functional deficiencies, being the cause of $15 \%$ of postnatal deaths in animals (FELIPE, 2003; MARCOLONGO-PEREIRA et al., 2010).

\footnotetext{
*Corresponding author:

Fabrício Bernardo de Jesus Brasil, DVM, PhD, Veterinary Hospital, Faculty Dr. Francisco Maeda, Educational Foundation of Ituverava, Rodovia Jerônimo Nunes Macedo, Km 01, Aeroporto, 14500-000, Ituverava, SP, Brazil, Phone: +55 1637299060 ; E-mail: fbjbrasil@yahoo.com.br
} 
In humans, polymelia (the presence of extra limbs) is a rare condition and information on its occurrence is scarce. There is no classification or data regarding its frequency of occurrence, the location of the extra limbs or its association with other congenital abnormalities (VERMA et al., 2013; MONTALVO et al., 2014). In animals, there are reports of polymelia in calves (BEHRENS et al., 1993; CEBRIÁN et al., 2006; MONTES et al., 2012), sheep (AHMADY and LISEY, 2009), amphibians (MAHAPATRA et al., 2001), reptiles (CUPUL-MAGAÑA et al., 2014), poultry (HIRSCHBERG et al., 2012), wild birds (ROGERS et al., 2016), and one case report in dogs (ZUCKER et al., 1993).

Intestinal duplication is rare in humans and animals, and is often associated with other major abnormalities of the spine, bladder and genitalia (LONGHOFER et al., 1991; ARTHUR et al., 2003; KUME et al., 2007; LIAQAT et al., 2014; HU et al., 2016). In animals, there have been three case reports in dogs (JOHNSTON et al., 1989; LONGHOFER et al., 1991; ARTHUR et al., 2003) and one in cats (KRAMER et al., 2007).

Thus, the objective of this report is to describe a case of polymelia associated with the duplication of the descending colon in a Poodle dog.

\section{Case history}

A six-month old female Poodle dog, weighing $4.8 \mathrm{~kg}$, was admitted to the veterinary hospital with a congenital third hind limb which was slightly displaced to the left and above the coccygeal vertebrae (Fig. 1).
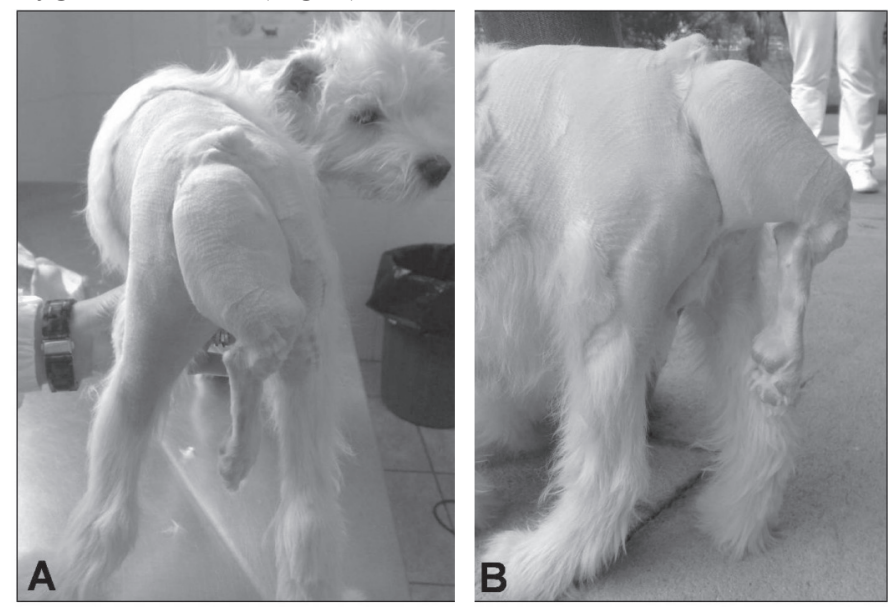

Fig. 1. Observe the aspect and the location of the insertion of the extra limb. A caudal image (A) and a left lateral image (B). 
According to the owner, the pup was able to walk normally, however it showed signs of distress and discomfort when sitting and defecating. The pup's littermates showed no signs of anatomical abnormalities. Its parents were not relatives and the mother had no accidents during gestation nor did she take any medications. The owner maintained contact with the owners of the parents of the pup to verify that all information regarding the gestation and birth were accurate.

During the clinical exam it was observed that the extra limb was static and smaller than the others. The animal had afferent and efferent sensitivities and was responsive to stimuli. There were no neurological alterations in the other limbs. The anal opening, contralateral to the extra limb, was sensitive and responded to touch stimuli. During the abdominal palpitation, there were no signs of distention or pain.

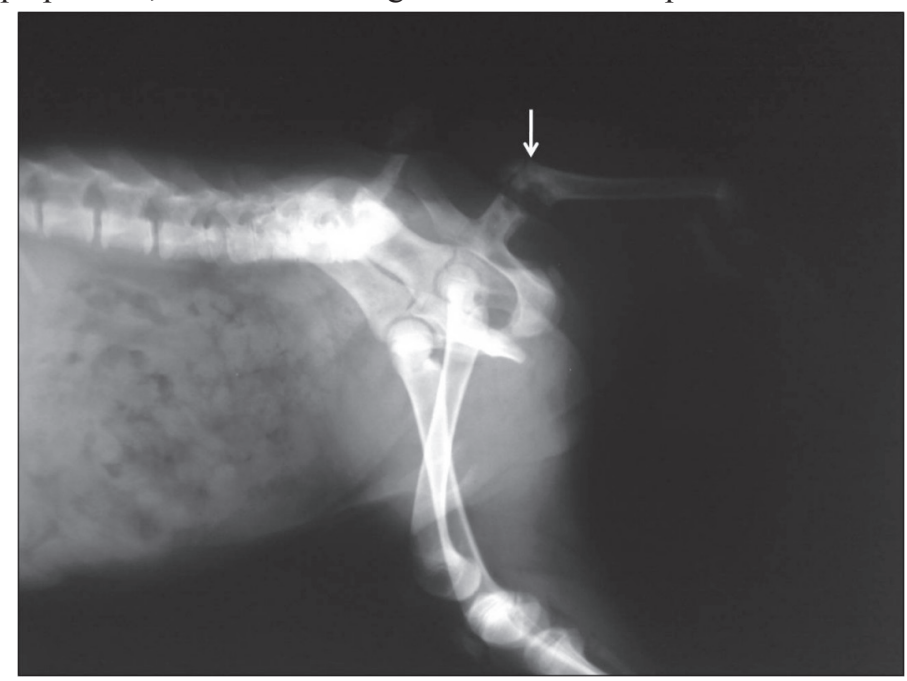

Fig. 2. Latero-lateral radiography of the extra limb articulated to the left ischium (arrow)

A plain radiography showed that the extra limb articulated from the left ischium bone, next to the ischial tuberosity. Only the femur bone was visible in the radiographic photos (Fig. 2). Through palpation, it was possible to see that the extra limb was whole and complete, consisting of the femur bone, tibia and fibula, metatarsals and phalanges. All the bones in the extra limb were small when compared to the bones of the pelvic limbs. With the animal presenting signs of discomfort when defecating, a contrast radiography was performed using oral and anal sulfate barium solution as the contrast $(8 \mathrm{~mL} / \mathrm{kg})$. This exam showed that the descending colon was duplicated, adjoining the segments in the rectum, and with one anal orifice (Fig. 3). 
E. R. Daneze and F. B. J. Brasil: Polymelia and duplication of the descending colon in a Poodle dog

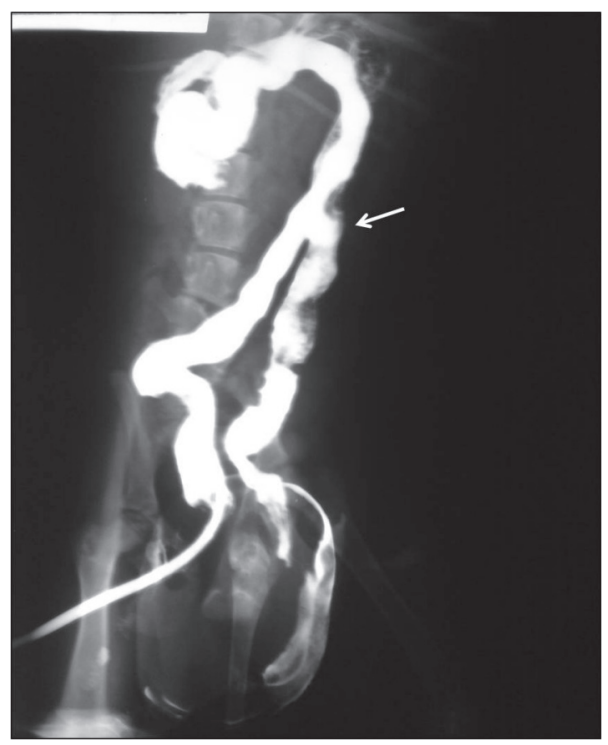

Fig. 3. Ventrodorsal contrast radiography showing the bifurcation where duplicated descending colon originates

After the pre-anesthetic tests (CBC, renal and hepatic profiles) which yielded results within the normal range for dogs, the animal underwent surgery to remove the extra limb. Surgery was not performed on the descending colon as it was deemed unnecessary at that time.

Pre-anesthetic medication was administered with acepromazine $(0.08 \mathrm{mg} / \mathrm{kg} \mathrm{IV})$ and tramadol (3 mg/kg IV), propofol was used for the induction ( $5 \mathrm{mg} / \mathrm{kg} \mathrm{IV}$ ) and anesthesia was maintained using isofluorane at $100 \%$ vaporized oxygen in a universal vaporizer. The pelvic area was prepared for aseptic surgery and supportive fluid therapy was maintained throughout the procedure.

First, an elliptical incision was made $3.0 \mathrm{~cm}$ from the insertion of the extra limb. The fascia was then cut carefully in order to avoid cutting any large blood vessels. The larger blood vessels, namely the femoral, medial circumflex femoral and lateral circumflex femoral arteries, and the veins that supplied the accessory limbs, were double ligated (number 0/4 catgut) and severed, and the small bleeders were controlled using electric cautery. No nerve branches were observed.

The gluteus superficialis, biceps femoris and internal obturator muscles were incised carefully to reach up the body to the ischium. The joint of the extra limb was located near the ischial tuberosity. The extra limb had a structure resembling a femur head, with a 
shallow articular surface in the ischium body and with a true joint at the attachment. The capsule of the joint was incised and the head of the femur was easily disarticulated from the left ischium, resulting in a minimally invasive procedure. Afterwards, the musculature and subcutaneous tissues were approximated with an absorbable polyglycolic suture in a simple continuous standard. The skin was sutured with nylon in an interrupted horizontal mattress standard.

Upon examining the dissected amputated limb, it was evident that all bones were complete, but they were smaller in size compared to the bones of the pelvic limbs of the animal. Only the femur had bone consistency, the tibia and fibula, metatarsals and phalanges were complete and had cartilaginous consistency. No histological examination of the extra limb tissues was conducted.

The animal remained under observation until fully recovered from the anesthesia. During the post-operative period, the surgical wound was cleaned with a physiological solution and a topic instillation of ryphamphcyne (every 8 hours). Apart from topical treatment, oral tramadol (3 mg/kg, every 8 hours, for 7 days), oral dipyrone $(20 \mathrm{mg} / \mathrm{kg}$, every 12 hours, for 7 days) and oral cephalexin (30 mg/kg, every 12 hours, for 15 days) were given.

The sutures were removed fifteen days after surgery. The owner said that the animal had no signs of pain, and seemed comfortable when sitting and defecating. There were no signs of edema or discoloration around the wound and it was healing well and normally.

Regarding the duplicated descending colon, the owner was informed that after the amputation of the extra limb, the animal would adapt well to its morphological condition and live a healthy life. He was also advised not to allow his dog to reproduce and to contact the surgical team whenever necessary.

\section{Discussion}

Congenital malformations originate from disturbances in embryogenesis, the organogenesis being the most affected period. They may be related to the erratic spread of germ cells in the embryo, or to the abnormal duplication of those cells at the beginning of the embryo development (CEBRIÁN et al., 2006; AHMADY and LISEY, 2009; McGEADY et al., 2006).

Extra limbs have no function (FELIPE, 2003; HIRSCHBERG et al., 2012). However, walking difficulties can cause distress to the animal. In this case, the location of the insertion of the extra limb did not have an effect on the animal's walking, but the animal was uncomfortable when sitting or defecating, which caused a considerable amount of distress. Thus, surgical excision of the extra limb was performed. This surgical intervention is recommended since additional limbs can interfere with the development 


\section{E. R. Daneze and F. B. J. Brasil: Polymelia and duplication of the descending colon in a Poodle dog}

and conformation of adults (MONTES et al., 2012) and it also provides comfort to the animal.

After a thorough clinical evaluation, the animal was deemed eligible for the surgical procedure and the excision was performed. Accessing and dislocating the limb was done with ease. In a case report by CEBRIÁN et al. (2006), involving a similar procedure in the surgical excision of a thoracic extra limb in a calf, the authors stated that there were no difficulties during the procedure and that the postoperative recovery was satisfactory, similar to this report.

It is known that the normal embryonic development of a limb (bud limb or appendage) consists of an ectodermal sheath covered by mesenchymal cells, which also contain specific regions which shape the contour of the limbs along the anteroposterior, dorsal-ventral and proximal-distal axis. The polarizing activity zone organizes the anteroposterior axis and the apical ectodermal ridge promotes the development of the bud limb, keeping the subjacent mesenchymal cells in the progress zone in an undifferentiated stage (McGEADY et al., 2006; BÉNAZET and ZELLER, 2009). Studies on chicks, Drosophila sp. and Bufo melanostictus indicate that when a piece of tissue from the polarizing activity zone is inserted into an anterior zone of the bud limb, this graft induces the formation of a mirror limb. Thus, the endogenously inserted tissue from the polarizing activity zone releases a morphogen (retinoic acid) that induces the apical ectodermal ridge expression of FGF4 (fibroblast growth factor 4). Both the retinoic acid and FGF4 activate the mesenchymal expression of the SONIC HEDGEHOG $(\mathrm{SHH})$ gene, establishing a new polarizing activity zone that culminates in the development of extra limbs (EICHELE, 1989; RIDDLE et al., 1993; MAHAPATRA et al., 2001).

The causes for the occurrence of these embryological disorders could be genetic, environmental (infectious agents, toxic plants, chemical substances, physical damage and nutritional deficiencies) or multifactorial (FELIPE, 2003; McGEADY et al., 2006; RADOSTITS et al., 2007; HIRSCHBERG et al., 2012), varying according to the type of agent and gestational period, and may occur in any anatomical region (AHMADY and LISEY, 2009). However, malformations can occur in a sporadic way with no specific cause (FELIPE, 2003; McGEADY et al., 2006; RADOSTITS et al., 2007) which could be the case with the animal in this study, since there were no accidents reported with the progenitors and no medications were administered during gestation. It is important to note that the pup was the only one in its litter that was affected.

Regarding the functional duplication of the descending colon in animals, only three cases have been reported in dogs (JOHNSTON et al., 1989; LONGHOFER et al., 1991; ARTHUR et al., 2003). In humans, intestinal duplications are very rare (KUME et al, 2007; LIAQAT et al., 2014; HU et al., 2016); even though it may occur from the oral cavity to the anus (HEISS, 1996; LIAQAT et al., 2014), descending colon duplication is 
extremely rare (SALVADOR et al., 1996). The occurrence of enteric duplication varies greatly and is usually mistaken for other gastrointestinal tract pathologies. Sometimes its presentation is confusing because patients may present with palpable abdominal or inguinal pain and/or an abdominal mass (LIAQAT et al., 2014). Colon duplication may be discovered accidentally while performing a colostomy (LIAQAT et al., 2014; HU et al., 2016) or contrast radiography (KUME et al, 2007).

The embryological explanation of the duplication of the colon is controversial and many theories have been proposed (STERN and WARNER, 2000; HU et al., 2016). One of the most common and accepted is the incomplete separation of mono-ovular twins or conjoined twinning as a result of the misexpression of one or more of the distal HOX genes, potentially HOX10 and HOX11 (SHAH and JOSHI, 2006; HU et al., 2016). In this case report, since the animal presented with a duplication of the descending colon and one anal orifice, it was presumed that the animal could adapt to its morphological condition and live a healthy life. The owner was told to contact the surgical team whenever necessary.

Altogether, detecting and explaining the etiology of congenital malformations is still a challenge in veterinary practice, especially since the majority of those defects occur rarely and are observed in only a few cases (LEIPOLD et al., 1972). Only in uncommon conditions, when a defect repeatedly occurs within the same herd or geographic area, does it become a target of investigation (LEIPOLD et al., 1983).

Regarding the duplicated descending colon, the owner was informed that after amputating the extra limb the animal could adapt to its morphological condition and lead a healthy life. Since the exact cause for this developmental anomaly is unclear it was recommended not to use the animal for breeding.

In this case, the operative removal of the extra limb was carried out successfully. The animal recovered well since the operation was performed under proper aseptic conditions and appropriate post operative care was given. Fifteen days after the operation, the animal was examined further and was found to be quite normal.

\section{References}

AHMADY, E. B., M. B. L. LISEY (2009): Notification of abnormalities in a lamb. Rev. Electrón. Vet. 10, 1-10 (in Spanish).

ARTHUR, E. G., D. B. FOX, S. C. ESSMAN, S. TURNQUIST, P. J. BONDY JR (2003): Surgical treatment of noncommunicating duplication of the colon in a dog. J. Am. Vet. Med. Assoc. 223, 210-214.

BEHRENS, C., A. KUCZKA, E. GRUNERT (1993): An unusual combination of different organ and skeletal abnormalities in a black and white calf. Tierärztl. Prax. 21, 185-187. 
E. R. Daneze and F. B. J. Brasil: Polymelia and duplication of the descending colon in a Poodle dog

BÉNAZET, J. D., R. ZELLER (2009): Vertebrate limb development: moving from classical morphogen gradients to an integrated 4-dimensional patterning system. Cold Spring Harb. Perspect. Biol. 1, a001339.

CEBRIÁN, L. M., E. VARELA, M. J. CIUDAD, J. J. RAMOS (2006): Polymelia in a Frisian calf eight days old: surgical treatment. Boletín Anembe 66, 4 (in Spanish).

CUPUL-MAGAÑA, F. G., R. G. QUEVEDO-MACHAIN, J. A. TOVAR-RAMOS, J. A. CURIELBELTRÁN (2014): Duplication of forelimb in Iguana iguana (Linnaeus, 1758): case report. Cuad. Herpetol. 28, 1-3 (in Spanish).

EICHELE, G. (1989): Retinoic acid induces a pattern of digits in anterior half wing buds that lack the zone of polarizing activity. Development 107, 863-867.

FELIPE, A. E. (2003): Introduction to teratology: the study of congenital malformations in veterinary medicine. Rev. Electron. Vet. 4, 1-4. Available from: http://www.veterinaria.org/ revistas/redvet/n040403.html (29/02/2016) (in Spanish).

HEISS, K. (1996): Intestinal duplications. In: Surgery of infants and children. (Oldham, K. T., P. M. Colombani, R. P. Foglia, Eds.), Lippincott Raven Publishers, New York, pp. 1257-1267.

HIRSCHBERG, R. M., M. SALEH, S. KAISER, M. LIERZ, H. M. HAFEZ, H. H. BRAGULLA (2012): Polymelous layer chick displaying additional malformations of the hind gut: case report and in-depth review of related literature. Anat. Histol. Embryol. 41, 262-273.

HU, T., T. BROWNING, K. BISHOP (2016): Caudal duplication syndrome: imaging evaluation of a rare entity in an adult patient. Radiol. Case Rep. 11, 11-15.

JOHNSTON, S. D., N. C. BAILIE, D. W. HAYDEN, G. R. JOHNSTON, C. A. OSBORNE (1989): Diphallia in a mixed-breed dog with multiple anomalies. Theriogenology 31, 1253-1260.

KRAMER, A., A. E. KYLES, P. LABELLE (2007): Surgical correction of colonic duplication in a cat. J. Am. Anim. Hosp. Assoc. 43, 128-131.

KUME, K., H. SAKATA, M. OTSUKI (2007): Gastrointestinal: Tubular duplication of the descending colon. J. Gastroenterol. Hepatol. 22, 1553.

LEIPOLD, H. W., K. HUSTON, S. M. DENNIS (1983): Bovine congenital defects. Adv. Vet. Sci. Comp. Med. 27, 197-271.

LEIPOLD, H. W., S. M. DENNIS, K. HUSTON (1972): Congenital defects of cattle: nature, cause, and effect. Adv. Vet. Sci. Comp. Med. 16, 103-150.

LIAQAT, N., T. LATIF, F. A. KHAN, A. IQBAL, S. I. NAYYAR, S. H. DAR (2014): Enteric duplication in children: a case series. Afr. J. Paediatr. Surg. 11, 211-214.

LONGHOFER, S. L., R. K. JACKSON, A. J. COOLEY (1991): Hindgut and bladder duplication in a dog. J. Am. Anim. Hosp. Assoc. 27, 97-100.

MAHAPATRA, P. K., P. MOHANTY-HEJMADI, S. K. DUTTA (2001): Polymelia in the tadpoles of Bufo melanostictus (Anura: Bufonidae). Curr. Sci. 80, 1447-1451.

MARCOLONGO-PEREIRA, C., A. L. SCHILD, M. P. SOARES, J. R. VARGAS, F. RIETCORREA (2010): Congenital defects diagnosed in ruminants in southern at Rio Grande do Sul. Pesq. Vet. Bras. 30, 816-826 (in Portuguese). 
E. R. Daneze and F. B. J. Brasil: Polymelia and duplication of the descending colon in a Poodle dog

McGEADY, T. A., P. J. QUINN, E. S. FITZPATRICK, M. T. RYAN, S. CAHALAN (2006): Veterinary Embryology. Wiley-Blackwell, Hoboken, NY, USA.

MONTALVO, N., L. REDROBÁN, V. H. ESPÍN (2014): Incomplete duplication of a lower extremity (polymelia): a case report. J. Med. Case Rep. 8, 184.

MONTES, V. D., P. A. ESPITIA, M. E. PRIETO (2012): Polymelia description in a commercial calf Brahman, case report. Rev. Colombiana Cienc. Anim. 4, 259-265 (in Spanish).

RADOSTITS, O. M., C. C. GAY, K. W. HINCHCLIFF, P. D. CONSTABLE (2007): Veterinary Medicine: a textbook of the diseases of cattle, horses, sheep, pigs, and goats. $10^{\text {th }}$ ed., Saunders Elsevier, Philadelphia, pp. 132-137.

RIDDLE, R. D., R. L. JOHNSON, E. LAUFER (1993): Sonic hedgehog mediates the polarizing activity of the ZPA. Cell 75, 1401-1416.

ROGERS, K. H., A. METE, S. MCMILLIN, R. SHINN (2016): Polymelia and syndactyly in a swainson's hawk (Buteo swainsoni). J. Wildl. Dis. 52, 114-117.

SALVADOR, I. I., M. E. S. MODELLI, C. R. PEREIRA (1996): Colon duplication: case report and literature review. J. Pediatr. 72, 254-257 (in Portuguese).

SHAH, K. R., A. JOSHI (2006): Complete genitourinary and colonic duplication: a rare presentation in an adult patient. J. Ultrasound Med. 25, 407-411.

STERN, L. E., B. W. WARNER (2000): Gastrointestinal duplications. Semin. Pediatr. Surg. 9, 135-140.

VERMA, S., M. KHANNA, V. N. TRIPATHI, N. C. YADAV (2013): Occurrence of polymelia in a female child. J. Clin. Imaging Sci. 3, 18.

ZUCKER, S. A., M. V. ROOT, S. D. JOHNSTON (1993): Diphallia and polymelia in a dog. Canine Practice 18, 15-19.

Received: 22 September 2016

Accepted: 5 March 2017

\section{DANEZE, E. R., F. B. J. BRASIL: Višak ekstremiteta (polymelia) i udvostručenje donjega dijela debelog crijeva u psa pasmine pudl - prikaz slučaja. Vet. arhiv 88, 149-157, 2018. SAŽETAK}

Istraživanje opisuje ženku pasmine pudl, u dobi od 6 mjeseci, koja je okoćena s trećim stražnjim ekstremitetom i udvostručenim donjim dijelom debelog crijeva. Prekomjerni ekstremitet bio je usmjeren dorzalno, prema repnom dijelu kralježnice, i malo pomaknut lijevo od središnje osi tijela, pored anusa. Iako je životinja hodala bez poteškoća, pokazala je znakove neudobnosti pri defekaciji i sjedenju. Standardni radiograf pokazao je da je dodatni ekstremitet u zglobu s lijevim dijelom sjedne kosti, a kontrastni radiograf da donji dio debelog crijeva nije samo udvostručen nego i povezan s dijelom rektuma koji završava jednim analnim otvorom. Učinjena je operacija kako bi se dodatni ekstremitet amputirao. Njegovo odvajanje iz zgloba s lijevim dijelom sjedne kosti bilo je lako izvedeno i minimalno invazivno. Intervencija na crijevu nije provedena jer je utvrđeno da životinja može živjeti zdrav život s dupliciranim debelim crijevom. Petnaest dana nakon operacije životinja nije pokazivala nikakve znakove nelagode pri sjedenju i defekaciji.

Ključne riječi: razvojna anomalija; pas; duplicirano debelo crijevo; embriologija; polymelia; radiologija

Vet. arhiv 88 (1), 149-157, 2018 
